\title{
Price Setters and Price Takers in the EU Electricity Market, a Comparative Analysis of Household Consumer Prices.
}

\author{
Aranit Shkurti ${ }^{1}$, Macit $\mathrm{Koc}^{2}$
}

\begin{abstract}
The article is concerned with the analysis of the electric power prices at the European spot exchanges, taking in consideration 27 Countries of the Union (excluding UK). The time series data are considering the half yearly average of the countries, as reported by the Eurostat database. The article examines the way spot prices are influenced by power exchanges, based on the overall installed power of more healthier economies. In recent years a growing capacity from renewable sources is pouring in the system, anyway the implementation of renewable energies do not guarantee constant supply to the network as they depend on weather conditions and therefore must still have recourse to conventional generation types - such as gas and coal - which generally have higher operating costs than renewable. An increasing number of Member States have adjusted mechanisms to promote investment in power plants or provided incentives to keep them standing. These public measures may be justified in certain situations but according to recent guidelines, the European Commission has established that the adjustment mechanisms can be in contrast with the legislation on state aid. The identification of these discrepancies is studied in this article through the key characteristics of the price differential for the EU spot markets. The inflation generated from the price adjustments within the EU members can be considered an important indicator of market inefficiency.
\end{abstract}

Key words: electricity spot exchanges, subsidies, price setter, price taker, household consumers.

\section{Introduction}

Price setter is generally considered a company that is able to fix or influence the price of a good or service that he produces or also acquires, due to the presence of certain market conditions that make it impossible or irrelevant for the other operators to apply any strategy normally accessible in a competitive market. This situation occurs if the market price setter is a big operator, who controls an important market share (as a seller as well as buyer), meanwhile the competitors are very weak because the market is fragmented and divided among a large number of operators, each of which is in the condition of a passive price taker. In these cases the buyer does not have the bargaining power to obtain reductions of the purchase price, while the seller does not have the power to raise the price, otherwise it will lose customers. Generally this approach is applied to private or public companies. Anyway in this paper we go further considering entire markets within the EU as price setters, meanwhile other markets can be defined as price takers or simply relatively independent markets. The above statement, in fact, should be considered specifically to the electricity market, due to its intrinsically unique 
characteristic as a public good. As it turns out, that power generation, transmission or distribution historically could only be provided by the state, through its enterprise. In the recent years deregulation has affected the electricity markets around Europe, due to specific directives or declared policies. Anyway most governments never gave up from directly or indirectly providing subsidies in the national energy market. In fact, public incentives specially oriented to the renewable energies have widened further the gap between healthy and developed markets with other markets, particularly referring to the East European members states. There is no doubt: the energy has been, it is and will be the focus of our lives, the ever shining symbol of development, growth, quality of life. As a strategic good, each state has intervened and will intervene in the sector to ensure its very survival.

Many considerations described above, given the political, economic and technological characteristics of the energy sector, led several European governments in the establishment of controlled state monopolies, or moreover consentient private monopolies. Once they achieved the goals that mentioned earlier, the abovementioned European states, under the Community stimulus, proceeded with the liberalization and privatization of the former monopolies in the other countries.

\section{Methodology}

The European Electricity Market is an electronic marketplace for gross electricity trading different for every member state, in which the price of energy corresponds to the equilibrium price obtained by the encounter between the electricity quantities demanded and supplied by operators who participate. The Power Exchange is not a mandatory market: operators, in fact, may enter into contracts also outside of the platform, through so-called bilateral contracts.

The network system, which characterizes the national electricity systems, provides that the transmission and dispatching activities are subject to very stringent technical constraints, such as:

- the demand for an instantaneous and continuous balance between the amount of energy fed into the grid and withdrawn from the network, the net of transport and distribution losses;

- the maintenance of the frequency and the voltage of the network within a narrow range, to protect the plant safety;

- the need for energy flows on each power line does not exceed the maximum permissible limits.

Even small deviations from any of the above parameters, for more than a few seconds, can quickly lead state of crisis of the system. The characteristics of the technologies and the means by which the electrical energy is produced, transported and consumed make further complicated compliance with these constraints. 
Table 1. Electricity prices by type of user EUR per kWh, medium size households

\begin{tabular}{|c|c|c|c|c|c|c|c|c|c|c|c|c|c|c|c|c|c|c|}
\hline $\begin{array}{l}\text { TIME } \\
\text { / Geo }\end{array}$ & $\begin{array}{l}200 \\
7 \mathrm{~S} 2\end{array}$ & $\begin{array}{l}200 \\
8 \mathrm{~S} 1\end{array}$ & $\begin{array}{l}200 \\
8 S 2\end{array}$ & $\begin{array}{l}200 \\
9 \mathrm{~S} 1\end{array}$ & $\begin{array}{l}200 \\
9 \mathrm{~S} 2\end{array}$ & $\begin{array}{l}201 \\
\text { OS1 }\end{array}$ & $\begin{array}{l}201 \\
\text { OS2 }\end{array}$ & $\begin{array}{l}201 \\
1 \mathrm{~S} 1\end{array}$ & $\begin{array}{l}201 \\
1 \mathrm{~S} 2\end{array}$ & $\begin{array}{l}201 \\
2 S 1\end{array}$ & $\begin{array}{l}201 \\
2 S 2\end{array}$ & $\begin{array}{l}201 \\
3 S 1\end{array}$ & $\begin{array}{l}201 \\
3 \mathrm{~S} 2\end{array}$ & $\begin{array}{l}201 \\
4 \mathrm{~S} 1\end{array}$ & $\begin{array}{l}201 \\
4 S 2\end{array}$ & $\begin{array}{l}201 \\
5 S 1\end{array}$ & $\begin{array}{l}201 \\
5 S 2\end{array}$ & $\begin{array}{l}201 \\
6 \mathrm{~S} 1\end{array}$ \\
\hline AT & 0,174 & 0,177 & 0,177 & 0,190 & 0,190 & 0,196 & 0,193 & 0,198 & 0,196 & 0,197 & 0,202 & 0,208 & 0,201 & 0,202 & 0,198 & 0,200 & 0,198 & 0,203 \\
\hline BE & 0,168 & 0,197 & 0,215 & 0,191 & 0,186 & 0,195 & 0,197 & 0,213 & 0,211 & 0,232 & 0,222 & 0,217 & 0,221 & 0,209 & 0,204 & 0,212 & 0,235 & 0,254 \\
\hline BG & 0,072 & 0,071 & 0,082 & 0,082 & 0,081 & 0,081 & 0,083 & 0,082 & 0,087 & 0,084 & 0,095 & 0,092 & 0,088 & 0,083 & 0,089 & 0,094 & 0,095 & 0,095 \\
\hline CY & 0,157 & 0,178 & 0,204 & 0,155 & 0,164 & 0,185 & 0,202 & 0,205 & 0,241 & 0,278 & 0,290 & 0,276 & 0,248 & 0,229 & 0,235 & 0,195 & 0,183 & 0,152 \\
\hline $\mathrm{CZ}$ & 0,117 & 0,140 & 0,142 & 0,145 & 0,153 & 0,149 & 0,154 & 0,165 & 0,162 & 0,166 & 0,166 & 0,168 & 0,164 & 0,138 & 0,137 & 0,138 & 0,140 & 0,142 \\
\hline DE & 0,210 & 0,214 & 0,219 & 0,228 & 0,229 & 0,237 & 0,243 & 0,252 & 0,253 & 0,259 & 0,267 & 0,291 & 0,292 & 0,298 & 0,297 & 0,295 & 0,294 & 0,296 \\
\hline DK & 0,240 & 0,263 & 0,278 & 0,269 & 0,255 & 0,267 & 0,270 & 0,290 & 0,297 & 0,299 & 0,297 & 0,3 & 0,293 & 0,304 & 0,303 & 0,306 & 0,304 & 0,308 \\
\hline $\mathbf{E E}$ & 0,078 & 0,081 & 0,085 & 0,092 & 0,092 & 0,097 & 0,100 & 0,097 & 0,104 & 0,109 & 0,112 & 0,135 & 0,136 & 0,130 & 0,132 & 0,130 & 0,129 & 0,120 \\
\hline EL & 0,098 & 0,104 & 0,109 & 0,115 & 0,103 & 0,118 & 0,121 & 0,125 & 0,123 & 0,139 & 0,141 & 0,156 & 0,169 & 0,176 & 0,178 & 0,176 & 0,177 & 0,176 \\
\hline ES & 0,14 & 0,136 & 0,155 & 0,157 & 0,168 & 0,172 & 0,185 & 0,198 & 0,208 & 0,219 & 0,227 & 0,222 & 0,227 & 0,216 & 0,236 & 0,230 & 0,237 & 0,218 \\
\hline FI & 0,114 & 0,122 & 0,127 & 0,129 & 0,128 & 0,132 & 0,137 & 0,154 & 0,157 & 0,154 & 0,155 & 0,157 & 0,155 & 0,156 & 0,153 & 0,155 & 0,153 & 0,154 \\
\hline FR & 0,122 & 0,121 & 0,120 & 0,120 & 0,120 & 0,128 & 0,135 & 0,138 & 0,142 & 0,139 & 0,150 & 0,152 & 0,159 & 0,158 & 0,162 & 0,162 & 0,167 & 0,168 \\
\hline HR & 0,098 & 0,099 & 0,118 & 0,115 & 0,116 & 0,115 & 0,115 & 0,113 & 0,114 & 0,120 & 0,138 & 0,137 & 0,135 & 0,131 & 0,132 & 0,131 & 0,131 & 0,131 \\
\hline HU & 0,129 & 0,154 & 0,155 & 0,148 & 0,166 & 0,170 & 0,157 & 0,168 & 0,155 & 0,154 & 0,161 & 0,139 & 0,132 & 0,120 & 0,114 & 0,112 & 0,114 & 0,111 \\
\hline IE & 0,191 & 0,176 & 0,203 & 0,203 & 0,185 & 0,180 & 0,187 & 0,190 & 0,208 & 0,215 & 0,228 & 0,229 & 0,240 & 0,240 & 0,253 & 0,242 & 0,245 & 0,230 \\
\hline IT & & 0,203 & 0,222 & 0,209 & 0,199 & 0,196 & 0,192 & 0,198 & 0,206 & 0,213 & 0,229 & 0,229 & 0,232 & 0,244 & 0,233 & 0,245 & 0,242 & 0,241 \\
\hline LT & 0,087 & 0,086 & 0,086 & 0,095 & 0,092 & 0,115 & 0,121 & 0,121 & 0,122 & 0,126 & 0,126 & 0,137 & 0,139 & 0,133 & 0,131 & 0,125 & 0,124 & 0,123 \\
\hline LU & 0,164 & 0,164 & 0,160 & 0,188 & 0,188 & 0,172 & 0,174 & 0,167 & 0,166 & 0,169 & 0,170 & 0,166 & 0,164 & 0,173 & 0,173 & 0,176 & 0,176 & 0,169 \\
\hline LV & 0,072 & 0,084 & 0,100 & 0,105 & 0,105 & 0,104 & 0,104 & 0,116 & 0,134 & 0,138 & 0,136 & 0,137 & 0,135 & 0,136 & 0,130 & 0,163 & 0,165 & 0,162 \\
\hline MT & 0,091 & 0,099 & 0,153 & 0,170 & 0,151 & 0,164 & 0,165 & 0,165 & 0,166 & 0,167 & 0,167 & 0,166 & 0,168 & 0,147 & 0,124 & 0,125 & 0,126 & 0,125 \\
\hline NL & 0,174 & 0,176 & 0,179 & 0,197 & 0,190 & 0,176 & 0,178 & 0,180 & 0,180 & 0,185 & 0,186 & 0,189 & 0,190 & 0,184 & 0,180 & 0,198 & 0,184 & 0,162 \\
\hline PL & 0,138 & 0,125 & 0,129 & 0,113 & 0,129 & 0,134 & 0,138 & 0,147 & 0,135 & 0,141 & 0,152 & 0,148 & 0,143 & 0,142 & 0,140 & 0,144 & 0,141 & 0,133 \\
\hline PT & 0,156 & 0,148 & 0,152 & 0,150 & 0,159 & 0,158 & 0,166 & 0,165 & 0,188 & 0,199 & 0,206 & 0,208 & 0,213 & 0,217 & 0,223 & 0,227 & 0,228 & 0,235 \\
\hline RO & 0,114 & 0,106 & 0,110 & 0,097 & 0,097 & 0,103 & 0,105 & 0,108 & 0,108 & 0,105 & 0,107 & 0,132 & 0,127 & 0,129 & 0,124 & 0,130 & 0,131 & 0,126 \\
\hline SE & 0,161 & 0,169 & 0,174 & 0,160 & 0,164 & 0,183 & 0,195 & 0,209 & 0,204 & 0,202 & 0,208 & 0,210 & 0,204 & 0,196 & 0,186 & 0,185 & 0,187 & 0,189 \\
\hline SI & 0,111 & 0,114 & 0,115 & 0,134 & 0,134 & 0,140 & 0,142 & 0,144 & 0,149 & 0,154 & 0,154 & 0,161 & 0,165 & 0,163 & 0,163 & 0,158 & 0,163 & 0,161 \\
\hline SK & 0,137 & 0,142 & 0,152 & 0,154 & 0,156 & 0,152 & 0,163 & 0,168 & 0,171 & 0,171 & 0,172 & 0,169 & 0,167 & 0,150 & 0,152 & 0,150 & 0,151 & 0,142 \\
\hline
\end{tabular}

Source of Data: Eurostat, Last update: 25.01.2017

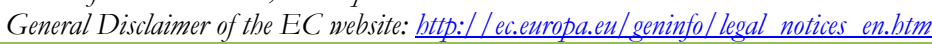

\begin{tabular}{llllllll}
\hline Belgium & $(\mathrm{BE})$ & Greece & (EL) & Lithuania & (LT) & Portugal & (PT) \\
\hline Bulgaria & (BG) & Spain & (ES) & Luxembourg & (LU) & Romania & (RO) \\
Czech Republic & (CZ) & France & (FR) & Hungary & (HU) & Slovenia & (SI) \\
Denmark & (DK) & Croatia & (HR) & Malta & (MT) & Slovakia & (SK) \\
Germany & (DE) & Italy & (IT) & Netherlands & (NL) & Finland & (FI) \\
Estonia & (EE) & Cyprus & (CY) & Austria & (AT) & Sweden & (SE) \\
Ireland & (IE) & Latvia & (LV) & Poland & (PL) & & \\
\hline
\end{tabular}


The analysis of electricity prices for households is based on prices for the medium standard household consumption band, namely one with annual electricity consumption between 2500 and $5000 \mathrm{kWh}$. This indicator presents electricity prices charged to final consumers. Until 2007 the prices are referring to the status on 1 st January of each year for medium size consumers (Standard Consumer Ie with annual consumption of $2000 \mathrm{MWh}$ ). Electricity prices for household consumers are defined as follows: Average national price in Euro per $\mathrm{kWh}$ including taxes and levies applicable for the first semester of each year for medium size household consumers (Consumption Band Dc with annual consumption between 2500 and $5000 \mathrm{kWh}$ ). Until 2007 the prices are referring to the status on 1st January of each year for medium size consumers (Standard Consumer Dc with annual consumption of $3500 \mathrm{kWh}$ ).

Table 2. Summary statistics, Electricity prices by type of user EUR per kWh, medium size households, period 2007S1 to 2016S1

\begin{tabular}{|c|c|c|c|c|c|c|}
\hline Variable & Obs & Mean & Std. Dev. & Min & $\operatorname{Max}$ & $\begin{array}{l}\text { Overall } \\
\text { Growth }\end{array}$ \\
\hline $\mathrm{AT}$ & 18 & .1949444 & .0096032 & .174 & .2082 & $16,90 \%$ \\
\hline $\mathrm{BE}$ & 18 & .2104167 & 0198437 & .1683 & .2544 & $51,16 \%$ \\
\hline $\mathrm{BG}$ & 18 & .0857111 & .0073362 & .0711 & .0957 & $32,59 \%$ \\
\hline CY & 18 & .2101944 & .0438641 & .1527 & .2909 & $-2,92 \%$ \\
\hline CZ & 18 & .1497889 & .0139537 & .1176 & .1681 & $20,75 \%$ \\
\hline $\mathrm{DE}$ & 18 & .2601556 & .0322636 & .2105 & .2981 & $41,05 \%$ \\
\hline DK & 18 & .2862056 & .0204303 & .2401 & .3088 & $28,61 \%$ \\
\hline $\mathrm{EE}$ & 18 & .1091722 & .0198318 & .0786 & .1367 & $53,69 \%$ \\
\hline EL & 18 & .1395278 & .029865 & .0984 & .1785 & $78,86 \%$ \\
\hline ES & 18 & .1977444 & .0342901 & .1366 & .237 & $56,07 \%$ \\
\hline FI & 18 & .1444833 & .014621 & .1149 & .1578 & $34,12 \%$ \\
\hline FR & 18 & .1427278 & .0177834 & .1203 & .1685 & $37,89 \%$ \\
\hline HR & 18 & .1219444 & .0121722 & .0984 & .1384 & $33,23 \%$ \\
\hline $\mathrm{HU}$ & 18 & .1426444 & .0209083 & .1114 & .1701 & $-14,04 \%$ \\
\hline IE & 18 & .2141333 & .025293 & .1769 & .2536 & $20,23 \%$ \\
\hline IT & 17 & .2200529 & .0186272 & .192 & .245 & $25,81 \%$ \\
\hline LT & 18 & .1163722 & .0182072 & .086 & .1391 & $41,49 \%$ \\
\hline LU & 18 & .17165 & .0075364 & .1609 & .1882 & $3,22 \%$ \\
\hline LV & 18 & .1241833 & .0265496 & .0729 & .165 & $123,32 \%$ \\
\hline MT & 18 & .1471889 & .0252228 & .0918 & .1708 & $36,93 \%$ \\
\hline NL & 18 & .1831278 & .0087228 & .162 & .1986 & $-6,95 \%$ \\
\hline PL & 18 & .1377111 & .0093773 & .1131 & .1529 & $-3,48 \%$ \\
\hline P' & 18 & .1891333 & .0315476 & .1482 & .235 & $50,45 \%$ \\
\hline RO & 18 & .1147778 & .0123286 & .0976 & .1323 & $10,69 \%$ \\
\hline $\mathrm{SE}$ & 18 & .1886 & .0168277 & .1602 & .2101 & $17,42 \%$ \\
\hline SI & 18 & .1462056 & .0179199 & .1116 & .1657 & $44,98 \%$ \\
\hline SK & 18 & .1569778 & .0111521 & .137 & .1722 & $3,87 \%$ \\
\hline
\end{tabular}


Following the data in Table 1 the highest price of electricity for consumers was recorded in Denmark 0.3088 Euros. This should be due to the fiscal pressure, where more than two thirds $(69.1 \%)$ of the final price is including VAT, taxes and levies;

Among the EU Member States, the largest electricity price increases for consumers in recent times was between the second half of 2014 and the second half of 2015 were observed in Latvia $(25.67 \%$ ) Table 3 . The highest increase for the overall period was in Malta (54.68\%) between the first half of 2008 and the second half of 2008.

Other important increases were in Czech Republic (19.13\%) 2008S1, Poland (14.15) 2009S2, Lithuania (24.84\%) 2010S1, Cyprus in a series of years (8.77\%) 2010S2, (17.71\%) 2011S2, (15.25\%) 2012S1, Croatia (14.57\%) 2012S2, Romania (23.07\%) 2013S1, Greece (8.57\%) 2013S2. To be mentioned that Cyprus had again the highest decrease in electricity price in the period having an overall standard deviation of 0.0438 Euro. (Table 2)

The average increase for the whole of the EU-27 was $1.66 \%$, although there were several countries were the price of electricity fell like Cyprus Hungary, Netherlands and Poland. These countries were facing substantial falls in the price of electricity (Table2) charged to household consumers in a period of 9 years.

Meanwhile the highest growth rates were for Belgium, Estonia , Greece, Spain, Latvia $(123 \%)$ and Portugal (Table 2$)$

Table 2. Electricity prices growth rate (\%) medium size households, period 2007S1 to 2016S1

\begin{tabular}{|c|c|c|c|c|c|c|c|c|c|c|c|c|c|c|c|c|c|}
\hline $\begin{array}{l}\text { TIME } \\
\text { /Geo }\end{array}$ & $\begin{array}{l}2008 \\
\text { S1 }\end{array}$ & $\begin{array}{l}2008 \\
\text { S2 }\end{array}$ & $\begin{array}{l}2009 \\
\text { S1 }\end{array}$ & $\begin{array}{l}2009 \\
\text { S2 }\end{array}$ & $\begin{array}{l}2010 \\
\text { S1 }\end{array}$ & $\begin{array}{l}2010 \\
\text { S2 }\end{array}$ & $\begin{array}{l}2011 \\
\text { S1 }\end{array}$ & $\begin{array}{l}2011 \\
\text { S2 }\end{array}$ & $\begin{array}{l}2012 \\
\text { S1 }\end{array}$ & $\begin{array}{l}2012 \\
\text { S2 }\end{array}$ & $\begin{array}{l}2013 \\
\text { S1 }\end{array}$ & $\begin{array}{l}2013 \\
\text { S2 }\end{array}$ & $\begin{array}{l}2014 \\
\text { S1 }\end{array}$ & $\begin{array}{l}2014 \\
\text { S2 }\end{array}$ & $\begin{array}{l}2015 \\
\text { S1 }\end{array}$ & $\begin{array}{l}2015 \\
\text { S2 }\end{array}$ & $\begin{array}{l}2016 \\
\text { S1 }\end{array}$ \\
\hline AT & 2.24 & -0.39 & 7.73 & 0.00 & 3.04 & -1.88 & 2.90 & -1.06 & 0.51 & 2.48 & 2.87 & -3.07 & 0.15 & -1.68 & 1.11 & -1.29 & 2.57 \\
\hline $\mathrm{BE}$ & 17.17 & 9.13 & 10.97 & -2.71 & 5.10 & 0.77 & 8.21 & -0.80 & 9.82 & -4.47 & -2.25 & 1.93 & -5.33 & -2.58 & 4.06 & 10.63 & 8.16 \\
\hline $\mathrm{BG}$ & -1.39 & 15.75 & 0.00 & -0.61 & -0.61 & 2.09 & -0.48 & 5.81 & -3.20 & 12.88 & -3.25 & -4.55 & -5.67 & 7.57 & 5.25 & 1.59 & -0.10 \\
\hline CY & 13.16 & 14.61 & $\begin{array}{l}- \\
23.63 \\
\end{array}$ & 5.39 & 13.15 & 8.77 & 1.43 & 17.71 & 15.25 & 4.60 & -5.12 & -10.11 & -7.66 & 2.84 & $\overline{16.94}$ & -6.08 & $\begin{array}{l}- \\
16.92 \\
\end{array}$ \\
\hline $\mathrm{CZ}$ & 19.13 & 1.93 & 1.89 & 5.36 & -2.41 & 3.54 & 7.10 & -1.93 & 2.27 & 0.24 & 0.78 & -2.14 & $\begin{array}{l}- \\
15.62 \\
\end{array}$ & -0.65 & 0.44 & 1.66 & 0.85 \\
\hline $\mathrm{DE}$ & 2.04 & 2.19 & 3.96 & 0.53 & 3.53 & 2.65 & 3.69 & 0.12 & 2.53 & 3.12 & 9.08 & 0.07 & 2.05 & -0.23 & -0.77 & -0.17 & 0.78 \\
\hline DK & 9.75 & 5.69 & $\begin{array}{r}-3.09 \\
\end{array}$ & -5.34 & 4.50 & 1.42 & 7.39 & 2.34 & 0.71 & -0.83 & 0.94 & -2.13 & 3.61 & -0.23 & 1.09 & -0.85 & 1.51 \\
\hline $\mathrm{EE}$ & 3.56 & 4.42 & 8.47 & -0.22 & 5.43 & 3.51 & -3.09 & 7.09 & 5.18 & 2.46 & 20.30 & 1.18 & -4.39 & 1.38 & -1.74 & -0.84 & -6.43 \\
\hline EL & 6.40 & 4.97 & 5.00 & 10.57 & 14.44 & 2.54 & 3.22 & -0.96 & 12.36 & 1.94 & 10.23 & 8.57 & 4.12 & 1.02 & -1.01 & 0.23 & -0.62 \\
\hline ES & -2.43 & 13.98 & 1.28 & 6.79 & 2.61 & 7.12 & 7.02 & 5.40 & 4.89 & 3.88 & -2.07 & 2.02 & -4.75 & 9.33 & -2.45 & 2.64 & -7.81 \\
\hline FI & 6.44 & 4.09 & 1.81 & -0.54 & 2.79 & 3.40 & 12.41 & 2.14 & -1.53 & 0.65 & 1.22 & -1.20 & 0.26 & -1.60 & 0.91 & -1.42 & 0.72 \\
\hline FR & -0.74 & -0.82 & 0.25 & 0.08 & 6.30 & 5.22 & 2.44 & 2.82 & -2.11 & 7.83 & 1.53 & 4.72 & -0.69 & 2.21 & 0.25 & 3.14 & 0.60 \\
\hline HR & 0.61 & 19.60 & -2.79 & 1.13 & -1.12 & 0.17 & -1.39 & 0.79 & 5.41 & 14.57 & -0.87 & -1.60 & -2.81 & 0.91 & -0.53 & -0.38 & -0.08 \\
\hline $\mathrm{HU}$ & 19.44 & 0.32 & -4.51 & 12.07 & 2.35 & -7.47 & 6.86 & -7.67 & -0.26 & 4.45 & $\overline{13.66}$ & -5.08 & -9.35 & -4.66 & -1.66 & 1.60 & -2.71 \\
\hline IE & -7.77 & 14.92 & -0.15 & -8.62 & -2.75 & 3.94 & 1.39 & 9.73 & 3.31 & 6.22 & 0.26 & 4.79 & 0.08 & 5.36 & -4.34 & 1.15 & -6.03 \\
\hline IT & & 9.65 & -5.79 & -4.81 & -1.60 & -2.29 & 3.49 & 3.93 & 3.24 & 7.74 & -0.22 & 1.35 & 5.29 & -4.42 & 4.79 & -0.90 & -0.62 \\
\hline
\end{tabular}




\begin{tabular}{|c|c|c|c|c|c|c|c|c|c|c|c|c|c|c|c|c|c|}
\hline LT & -1.15 & 0.58 & 9.94 & -2.63 & 24.84 & 5.19 & -0.16 & 0.58 & 3.19 & 0.63 & 8.04 & 1.53 & -4.39 & -0.83 & -4.78 & -1.04 & -0.97 \\
\hline LU & 0.00 & -2.19 & 16.97 & 0.00 & -8.29 & 1.22 & -3.95 & -0.95 & 2.05 & 0.59 & -2.40 & -1.14 & 5.59 & 0.00 & 1.67 & 0.00 & -3.90 \\
\hline LV & 15.50 & 19.12 & 4.89 & 0.19 & -0.47 & -0.10 & 11.45 & 14.90 & 2.98 & -0.94 & 0.66 & -1.45 & 0.52 & -4.69 & 25.67 & 0.92 & -1.33 \\
\hline MT & 8.17 & 54.68 & 11.20 & -11.42 & 8.86 & 0.36 & -0.12 & 0.91 & 0.42 & 0.30 & -0.83 & 1.50 & 12.73 & $-\overline{15.33}$ & 0.72 & 0.95 & -0.95 \\
\hline NL & 1.61 & 1.64 & 10.07 & -3.69 & -7.29 & 1.25 & 0.73 & -0.06 & 2.72 & 0.76 & 1.82 & 0.37 & -3.36 & -2.17 & 10.27 & -7.05 & -12.24 \\
\hline PL & -8.77 & 2.86 & 12.66 & 14.15 & 3.87 & 3.06 & 6.44 & -8.16 & 4.96 & 7.83 & -3.20 & -2.91 & -1.11 & -0.91 & 2.56 & -1.80 & -6.06 \\
\hline PT & -5.12 & 2.90 & -1.11 & 5.70 & -0.63 & 5.18 & -0.72 & 13.72 & 5.95 & 3.51 & 0.87 & 2.40 & 2.06 & 2.57 & 2.15 & 0.26 & 2.84 \\
\hline $\mathrm{RO}$ & -7.01 & 3.96 & - 11.51 & 0.31 & 5.31 & 2.04 & 2.85 & 0.28 & -3.23 & 2.38 & 23.07 & -3.33 & 0.86 & -3.26 & 4.41 & 1.23 & -4.25 \\
\hline SE & 5.27 & 2.83 & -8.25 & 2.75 & 11.73 & 6.47 & 6.84 & -2.29 & -0.83 & 2.76 & 0.86 & -2.62 & -3.86 & -5.08 & -0.86 & 1.24 & 1.07 \\
\hline SI & 2.78 & 0.78 & 16.44 & -0.37 & 4.47 & 1.78 & 1.05 & 3.54 & 3.35 & 0.00 & 4.41 & 2.92 & -1.63 & 0.12 & -2.63 & 2.64 & -0.80 \\
\hline SK & 3.72 & 7.39 & 0.92 & 1.30 & -2.56 & 7.70 & 2.75 & 1.66 & 0.35 & 0.35 & -1.39 & -1.18 & 10.19 & 1.06 & -1.12 & 0.73 & -6.20 \\
\hline
\end{tabular}

Source of Data: Eurostat, Last update: 25.01.2017

\section{Results}

The mechanism for the management of electrical spot exchange in the EU still faces several obstacles toward the integration of the service. For the ongoing period there is not real convergence of the electricity prices for the household consumers. Sources of the market fragmentation can be lack of cooperation or less supervision by the European Agency for energy cooperation, as well as less transparency and more discriminating prices for final consumers. The governance of the electricity market with special attention to the renewable sources needs to be re-designed further. The current events are shaping thoroughly the traditional assumptions of the system.

The analysis of the present organization shows lack of coordination and transparency. Among some key elements for an electric European reform could be providing more awareness toward the grid limits and the demand centers rather than national borders. As shown from the previous tables the difference of prices in the European Union in the past 10 years faced high inflation specially for some East European countries. These increase may be is due to their less structured markets forced to challenge advanced electricity super powers like France and Germany. Basically this countries have failed to build new capacities and are depending on the EU electricity exchange market.

\section{Conclusions}

Some countries have dominant position in the market, so they can pilot the electricity prices through public incentives or other public policies. On April 9, 2014, the EU adopted new "Environmental and Energy State Aid Guidelines for 2014-2020". The Guidelines consider exemptions from renewable energy surcharges for industrial companies as state aid targeting mainly the Energiewvende German program. On July 23, 2014 the European Commission accepted a deal with the German government over the state incentives. 
The integration of the EU electricity market is a challenge for the member states, the convergence of the prices toward the wealthier economies has generated significant inflation for the new members and has widened the structural gap with the western countries. The research results show that unlike in the EU-15 (old Member States), energy sector reforms in the EU-12 (new Member States), and selected Southeast European countries have no impact in lowering the electricity prices or improving the overall efficiency. These results show that the EU model does not improve efficiency of electricity market within the less developed economies.

\section{References}

Atkinson, S.; Halvorsen, R. Interfuel substitution in steam electric power generation. J. Polit. Econ. 1976, 84, 959-978.

Butler, L.; Neuhoff, K. Comparison of feed-in tariff, quota and auction mechanisms to support wind power development. Renew. Energy 2008, 33, 1854-1867.

Caves, D.; Christensen, L. Global properties of flexible functional forms. Am. Econ. Rev. 1980, 70, 422-432.

Cini Michelle and McGowan Lee, (1998). Competition Policy in the European Union, Macmillan, Houndmills and London.

Coen David, (2001). Business-Regulatory Interaction in German and UK Telecommunication and Energy Sectors: A Multi-Level and Multi-Institutional Study, Paper presented at the European Community Studies Association, Madison, 31 st May - 3 ${ }^{\text {rd }}$ June 2001.

Convery, F.J.; Redmond, L. Market and price developments in the European Union Emissions Trading Scheme. Rev. Environ. Econ. Policy 2007, 1, 88-111.

Cowles, M.G., J.A. Caporaso and T. Risse (eds.) (2001). Transforming Europe: Europeanization and Domestic Change. Ithaca, NY: Cornell University Press.

De Leyva, E.; Lekander, P. Climate change for Europe's utilities. McKinsey Q. 2003, 1, 120-131.

Delarue, E.; D'haeseleer, W. Price determination of ETS allowances through the switching level of coal and gas in the power sector. Energy Res. 2007, 31, 1001-1015.

Eising Rainer and Jabko Nicolas (2001). "Moving Targets: Institutional Embeddedness and Domestic Politics in the Liberalization of EU Electricity Markets", Comparative Political Studies, Vol. 34, No. 7 , pp. $742-767$.

Ellerman, A. The EU Emission Trading Scheme: Prototype of A Global System? The Harvard Project on International Climate Agreements; Kennedy School of Government, Harvard University: Cambridge, MA, USA, 2008.

Ellerman, A.; Buchner, B. The European Union Emissions Trading Scheme: Origins, allocation, and early results. Rev. Environ. Econ. Policy 2007, 1, 66-87.

Energy Price Statistics. United Kingdom Department of Energy and Climate Change: London, UK, 2012. Available online: http://www.decc.gov.uk/en/content/cms/statistics/energy_stats/prices/prices.aspx (accessed on 17 October 2012).

Financial Times Energy, (1997). Electricity in Europe: Into the Single Market, FT, London, Two Volumes.

Gilbert, J.R. and Kahn, P. Edward (1996). International Comparisons of Electricity Regulation. Cambridge: Cambridge University Press.

Schmidt, Vivien A. (2002). The Futures of European Capitalism, Oxford: Oxford University Press.

Schneider Volker and Vedel Thierry (1999). From High To Low Politics in Franco-German Relations, In Webber Douglas (ed.), The Franco-German Relationship in the European Union, Routledge: London and New York, pp. 75-92.

Watanabe, R.; Robinson, G. The European Union Emissions Trading Scheme (EU ETS). Clim. Policy 2005, $5,10-14$. 